\title{
PENGARUH FAKTOR-FAKTOR RISIKO PENUAAN DINI DI KULIT PADA REMAJA WANITA USIA 18-21 TAHUN
}

\author{
Marlina Dewiastuti* Irma Fathul Hasanah* \\ *Program Studi Kedokteran Umum, Fakultas Kedokteran, UPN “Veteran” Jakarta \\ Jl. RS Fatmawati, Pondok Labu, Jakarta Selatan 12450, Telp. (021) 7656971 \\ Homepage: http://www.jurnal.fk.upnvj.ac.id
}

\begin{abstract}
Abstrak
Proses penuaan kulit adalah proses dinamik. Proses penuaan kulit menyebabkan perubahan histologis pada lapisan kulit. Faktor-faktor yang mengakibatkan penuaan kulit adalah faktor intrinsik (status gizi) dan faktor ekstrinsik (sinar UV). Penelitian ini dilakukan di Fakultas Kedokteran UPN "Veteran" Jakarta. Tujuan penelitian ini ingin mengetahui prevalensi proses penuaan pada remaja, mencari hubungan antara faktor risiko dengan penuaan dini, serta faktor yang berpengaruh pada proses penuaan dini. Desain penelitian ini adalah potong lintang yang terdiri atas 136 subjek. Data yang dikumpulkan dianalisis univariat, bivariat, dan multivariat. Hasil univariat menunjukkan57,35\%terjadi penuaan dini, uji chi-square menunjukkan bahwa terdapat korelasi $(\mathrm{p}=0,001)$ antara pemakaian tabir surya dengan penuaan dini dan tidak terdapat hubungan antara status gizi dengan penuaan dini $(\mathrm{p}=0,246)$. Hasil multivariat faktor yang memengaruhi terjadinya penuaan dini adalah pemakaian tabir surya. Dari hasil uji tersebut penuaan dini terjadi pada remaja akhir dan faktor yang berpengaruh adalah pemakaian tabir surya.
\end{abstract}

Kata kunci : status gizi, pemakaian tabir surya, penuaan dini

Abstract

Skin aging process is a dynamic process. Skin aging process causes histologic change in skin layer. There are 2 factors causing skin aging process, intrinsic factor (nutritional status) and extrinsic factor (UV light).This research was conducted in a population of medical students of UPN Veteran Jakarta. The objective of this study was to ascertain prevalence of skin aging process and whether there was a relationship between the intrinsic and extrinsic factors and skin aging process. The design in this study was a cross-sectional study of the 136 research subjects. The collected data were analyzed by univariate, bivariate, and multivariate analysis. The incidence of skin aging process is $57.35 \%$. Chi-square test showed that there was a relationship between the application of sunscreen and skin aging process $(p=0.001)$. There was no significant relationship between nutritional status $(p=0,246)$ and skin aging process. From that result, skin aging process has occurred in late adolescent and most influence factor is application of sunscreen.

Keywords :Nutrional status, application of sun screen, aging process 


\section{PENDAHULUAN}

Proses penuaan kulit adalah proses dinamik. Proses penuaan kulit menyebabkan perubahan histologis pada lapisan kulit (Sadick, 2009). Faktor-faktor yang mengakibatkan penuaan kulit adalah faktor intrinsik dan faktor ekstrinsik. Faktor intrinsik yang menyebabkan terjadinya penuaan dini adalah peningkatan radikal bebas dan kerusakan DNA. Untuk faktor ekstrinsik yang memengaruhi terjadinya penuaan dini adalah sinar UV dan merokok(Kemmeyer A\&Luiten RM, 2015; Stojiljkovic et al, 2013, Hekimi et al, 2011).

Organ kulit dibentuk dari jaringan ikat yang terdiri atas jaringan yang terdiri atas komponen selular dan matriks ekstraseluler. Matriks ekstrasel mengandung 2 makromolekul utama, salah satunya kolagen. Kolagen yang nantinya akan dipengaruhi oleh proses penuaan(CallejaAgius J\&Brincat M, 2013).

Mekanisme penuaan kulit yang diakibatkan oleh faktor intrinsik dan ekstrinsik berbeda. Adanya gangguan pada faktor intrinsik mengakibatkan peningkatan radikal bebas dan pemendekan telomere yang nantinya akan menyebabkan penurunan produksi kolagen. Faktor ekstrinsik (sinar UV dan merokok) menyebabkan pertumbuhan abnormal elastin (Sadick SN et al, 2009).

Faktor intrinsik yang menyebabkan peningkatan radikal bebas adalah obesitas. Obesitas adalah kondisi kelebihan atau akumulasi abnormal jaringan lemak. Obesitas mengakibatkan reaksi inflamasi yang akan meningkatkan stress oksidatif dan pemendekan telomere(Tzanetakou IP et al, 2012).

Faktor ekstrinsik, yaitu sinar UV dan merokok, menyebabkan gangguan pada pembentukan elastin. Abnormalitas elastin mengakibatkan tipisnya jaringan dermis dan epidermis.

Manifestasi penuaan kulit ditandai dengan kerut, dimana kerut terjadi akibat kehancuran DNA akibat reaksi inflamasi yang akan menghasilkan protease dan spesies oksigen reaktif yang akan menghancurkan serat elastin. Bintik hitam diakibatkan oleh jumlah melanosit per unit. Lingkaran hitam, mekanisme penipisan jaringan kulit pada pembuluh darah terlihat pada permukaan kulit sehingga tampak kehitaman(Tzanetakou IP et al, 2012).

Pola proses penuaan kulit berbeda pada wanita asia dan kaukasia. Pada wanita Asia manifestasi penuaan kulit yang mucul adalah bintik hitam atau lentigenes, sedangkan pada wanita kaukasia manifestasi penuaan kulit adalah kerut(Sugita T\&Nishikawa A, 2011).

Tujuan penelitian ini adalah untuk menemukan prevalensi penuaan kulit pada remaja akhir. Mencari hubungan antara faktor risiko intrinsik (status gizi) dan faktor ekstrinsik (sinar UV) serta faktor yang paling berpengaruh pada proses penuaan kulit pada remaja akhir.

Desain penelitian ini adalah penelitian analitik dengan menggunakan metode studi potong lintang (cross sectional), pada populasi mahasiswa kedokteran. Penelitian ini dilakukan di Fakultas Kedokteran UPN Veteran Jakarta Jl.RS Fatmawati No. 1 Pondok Labu, Jakarta Selatan selama bulan Deesember 2015.

Penentuan sampel dalam penelitian ini dilakukan menggunakan probability sampling dengan simple random sampling.

Besar sampel dihitung melalui rumus analitik kategorik tidak berpasangan dan didapatkan hasil sebanyak 136 sampel mahasiswa. Kriteriakriteria sampel yang digunakan oleh penulis, yaitu menyangkut kriteria inklusi dan eksklusi. Kriteria inklusi :

a. Bersedia mengikuti penelitian dengan persetujuan tertulis maupun lisan dan bersedia mengikuti wawancara, mengisi kuesioner, dan pemeriksaan fisik.

b. Sehat dan mampu mengikuti penelitian ini. Kriteria eksklusi :

a. Mahasiswi yang merokok

Alat ukur yang digunakan untuk menilai adalah Glogau score dengan pengamatan langsung. Alat ukur untuk mengukur tinggi badan dan bobot badan digunakan stature meter dan timbangan injak. Penggunaan tabir surya dengan wawancara langsung mengenai penggunaan tabir surya yang benar.

Variabel terikat pada penelitian ini adalah penuaan kulit dan variabel bebas dalam penelitian ini adalah sebagai berikut:

a. Status gizi 
b. Penggunaan tabir surya

\section{PEMBAHASAN}

Gambaran Status Gizi

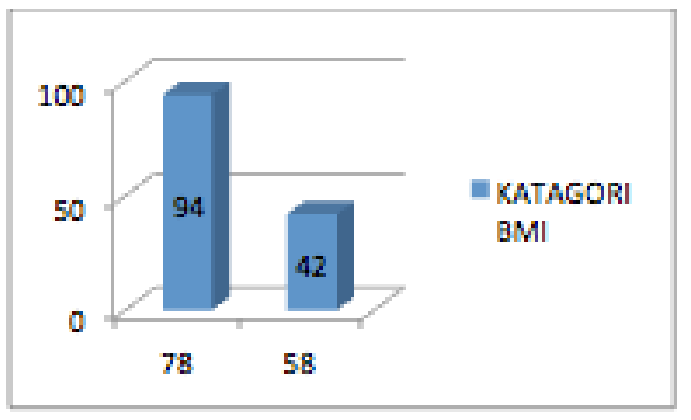

Grafik 1. Katagori BMI

Dari hasil penelitian didapatkan kebanyakan mahasiswi usia 18-21 memiliki status gizi normal, terdapat 42 orang berstatus gizi lebih dimana 21 diantaranya sudah tampak penuaan kulit.

Penuaan kulit pada status gizi normal dan lebih berpotensi sama untuk penuaan kulit. (Ahima, 2009; Jarold et al, 2013)

\section{Gambaran penggunaan tabir surya}

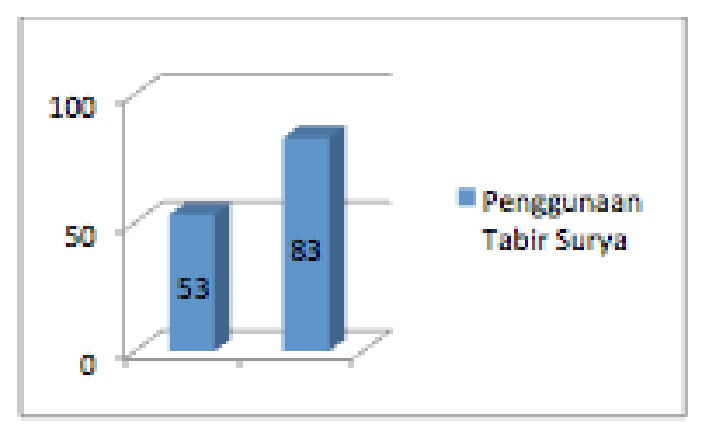

Grafik 2. Penggunaan Tabir Surya

Berdasarkan Grafik 2 didapatkan kebanyakan subjek penelitian tidak pernah menggunakan tabir surya atau tidak tepat dalam penggunaannya. Lima puluh delapan yang tidak memakai atau tidak tepat penggunaan tabir surya mengalami penuaan kulit dini.

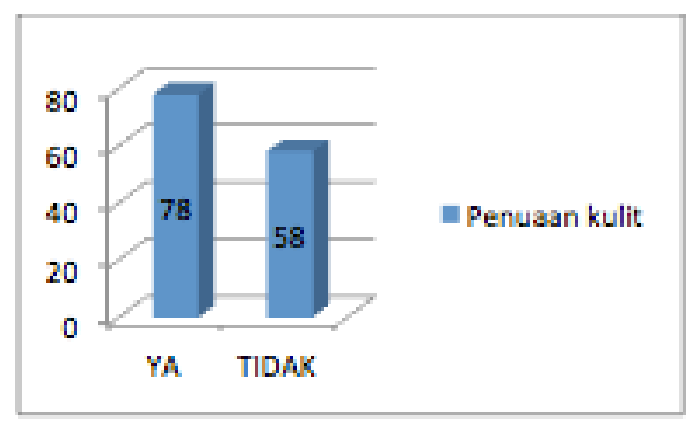

Grafik 3. Penuaan kulit

Dari hasil penelitian 136 responden mahasiswi usia 18-21 tahun, didapatkan jumlah mahasiswi yang mengalami penuaan kulit 78 orang (57,35\%).Terjadinya penuaan kulit dini pada remaja diakibatkan oleh terpaparnya sinar matahari, kebanyakan dari subjek yang mengalami penuaan dini adalah subjek yang tidak atau salah menggunakan tabir surya (Fisher et al., 1997).Kejadian penuaan dini pada penelitian ini cukup tinggi, seharusnya proses penuaan belum terjadi pada remaja akhir. Penuaan kulit seharusnya baru terjadi pada usia 28 tahun.

\section{Hubungan antara status gizi dengan penuaan kulit}

Hasil penelitian ini berdasarkan uji chi square diperoleh nilai $\mathrm{p}=0,246$ ( $\mathrm{p}>0,05)$ yang menunjukkan bahwa tidak terdapat hubungan yang bermakna antara status gizi dan penuaan kulit. Tabel. 1 Hubungan antara status gizi dengan penuaan kulit

\begin{tabular}{|c|c|c|c|c|}
\hline \multirow{3}{*}{$\begin{array}{c}\text { Status } \\
\text { gini }\end{array}$} & \multicolumn{2}{|c|}{ Penuaan kulit } & \multirow[b]{2}{*}{ Total } & \multirow{3}{*}{ P-value } \\
\hline & Tidak & $\overline{Y a}$ & & \\
\hline & $\mathrm{n}$ & $\mathrm{n}$ & $\mathrm{n}$ & \\
\hline Normal & 21 & 21 & 42 & \\
\hline Lebih & 37 & 57 & 94 & 0,246 \\
\hline Total & 58 & 78 & 136 & \\
\hline
\end{tabular}

Status gizi lebih atau obesitas terutama obesitas sentral memicu terbentuknya radikal bebasdan terbentuknya radikal bebas akan memicu respons inflamasi yang akan menyebabkan terjadinya proses penuaan. Proses penuaan yang terjadi pada keadaan obesitas lebih pada penuaan pada organ-organ tubuh dalam(Ahima, 2009). Penuaan pada kulit terjadi superfisial. Proses penuaan pada kulit yang dipengaruhi oleh status gizi juga dipengaruhi oleh kadar lemak dalam tubuh. Selain itu, proses penuaan kulit pertama secara histologis (Jarrold et al., 2013). Keterbatasan dalam penelitian ini ialahtidak diukur kadar lemak dalam tubuh dan biopsi kulit apakah sudah terjadi proses penuaan kulit mikroskopik. 


\section{Hubungan antara penggunaan tabir surya dengan penuaan kulit}

Hasil penelitian ini berdasarkan uji chi square diperoleh nilai $\mathrm{p}=0,01(\mathrm{p}<0,05)$ yang menunjukkan bahwa terdapat hubungan yang bermakna antara penggunaan tabir surya dan penuaan kulit.

Tabel. 2 Hubungan antara penggunaan tabir surya dengan penuaan kulit

\begin{tabular}{|c|c|c|c|c|}
\hline \multirow{3}{*}{$\begin{array}{c}\text { Penggunazn } \\
\text { tabir surya }\end{array}$} & \multicolumn{2}{|c|}{ Perroaan kulit } & \multirow[b]{2}{*}{ Total } & \multirow{3}{*}{ P-valu } \\
\hline & Tidak & $\mathrm{Ya}$ & & \\
\hline & $\mathrm{n}$ & $\mathrm{n}$ & $\mathrm{n}$ & \\
\hline Ya & 33 & 20 & 53 & \\
\hline Tidak & 25 & 58 & 83 & 0,001 \\
\hline Total & 58 & 78 & 136 & \\
\hline
\end{tabular}

Terpapar sinar matahari dalam jangka waktu yang lama menyebabkan penuaan kulit prematur dengan karakteristik timbulnya keriput dan bintik hitam. Sinar matahari meningkatkan ekspresi protein, yaitu kolagenase, gelatinase, dan stromelysin. Ketiga protein tersebut dapat mendegradasi matriks kulit sehingga timbul gejala penuaan kulit(Fisher et al., 1997; Tzanetakou, 2012).

\section{PENGARUH FAKTOR RISIKO INTRINSIK DAN EKSTRINSIK PADA PENUAAN KULIT}

Uji multivariat dilakukandengan uji regresi logistik metode Backward. Dengan uji HosmerLemeshow didapatkan nilai 0,352 yang berarti uji statistik ini tepat dilakukan dengan uji regresi logistik. Dari uji statistik regresi logistik metode Backward didapatkan faktor yang paling berpengaruh dari penelitian ini adalah penggunaan tabir surya. Penuaan kulit disebabkan oleh multifaktorial, seperti yang sudah disebutkan pada pendahuluan terdapat faktor intrinsik dan ekstrinsik penyebab penuaan kulit(Giacomoni, 2008; Dianasari, 2014). Akan tetapi pada penelitian ini didapatkan bahwa penggunaan tabir surya akan menangkal terpapar sinar UV sehingga mengahambat terjadi penuaan kulit prematur.

\section{KESIMPULAN}

Berdasarkan penelitian ini kebanyakan subjek penelitian sudah terjadi penuaan kulit pada remaja akhir. Faktor ekstrinsik (sinar UV) berhubungan dan berpengaruh pada terjadinya penuaan kulit, sedangkan status gizi tidak berhubungan dengan penuaan kulit.

\section{SARAN}

Berdasarkan hasil penelitian disarankan untuk penelitian selanjutnya dengan melakukan pemeriksaan mikroskopik kulit untuk melihat perubahan histologik kulit, memeriksa profil lipid dan kadar radikal bebas.

\section{DAFTAR PUSTAKA}

Ahima RS. 2009. Connectingobesity, aging and diabetes. Nature Medicine Vol. 15, pp. 996-997

Calleja-Agius j and Brincat M. 2013. Skin connective tissue and aging. Best Practice and research Obs \& Gyn. Vol. 27, pp 727-740

Dianasari R. 2014. Pemberian krim ekstrak jagungungu (Zea Mays) menghambat peningkatan kadar MMP-1 dan penurunan jumlah kolagen pada tikus wistar. Universitas Udayana (Thesis).

Fisher GJ, Wang Z, Datta S et al. 1997. Pathophysiology of premature skin aging induced by ultraviolet light. NEJM. Vol 337, pp 1419-28

Giacomoni P. 2008. Advancement in skin aging : the future cosmeceutical. Clininc in dermatology. Vol 26, pp 364-366

Hekimi S, lapointe J, Wen Y. 2011. Taking a "good" look at free radicals in the aging process. Cell Press Vol 21 (10)

Jarrold B, Tamura M, Osborne R. 2013. Expression profiles of cholesterol biosynthetic pathway associated with skin intrinsic and extrinsic aging. J A Acad Dermatol.

Kammeyer A, Luiten RM. 2015. Oxidation events and skin aging. Ageing research review. Vol 21 pp 16-29 
Saddick SN, Karcher C, Palmisano L. 2009. Cosmetic dermatology of the aging face. Clinics in dermatology. Vol 27, pp 3-12

Stojiljkovic D, Pavlovic D, Arsic I. 2014. Oxidative stress, skin aging and antioxidant therapy. Sci Journal. Vol 31(4), pp207-217

Sugita T, Nishikawa A. 2011. Asociation between sun-exposure, smoking behavior and plasma antioxidant level with the different manifestation os skin ageing signs between Japanes and German women-A pilot study. J of Derma Sci. Vol 62, pp 128-140

Tzanetakou IP, Katsilambros NL, Benetos A, et al. 2012. Is obesity linked to aging? Adipose tissue and the role of telomeres. Ageing research review. Vol 11, pp 220-9 